\title{
Parvovirus B19 and chronic arthritis-causal or casual association?
}

Since its identification in asymptomatic blood donors in 1975, human parvovirus B19 has been associated with a variety of clinical manifestations including erythema infectiosum, ${ }^{1}$ aplastic crises, ${ }^{2}$ hydrops fetalis, ${ }^{3}$ certain vasculitides $^{45}$ and an acute arthropathy. ${ }^{67}$ Nikkari et al ${ }^{8}$ propose in this issue that parvovirus B19 could be a trigger for rheumatoid arthritis in some patients.

The spectrum of outcome was demonstrated in a controlled epidemiological study, ${ }^{9}$ varying from an asymptomatic infection, a flulike illness often with a rash, to an acute arthropathy in $60 \%$ of women and $30 \%$ of men, and lasting more than two months in $20 \%$. Some of these patients, and others reported, ${ }^{6}{ }^{9}$ had an arthropathy at times clinically indistinguishable from rheumatoid arthritis, a few are seropositive for rheumatoid factor, ${ }^{10}$ and patients have been reported who developed erosive disease. ${ }^{811}$ Studies have therefore looked at the possible relationship between parvovirus B19 and rheumatoid arthritis. There are two principal difficulties in this line of enquiry: first, proving a causal relationship and second, the limitations of the methods of detection of recent or past parvovirus B19 infection. Chronic diseases caused by infectious agents, such as reactive arthritis, do not meet the Henle-Koch postulates, ${ }^{12}$ as they represent an unusual host response to a common infection. Controlled or long term prospective studies are required. Seroepidemiology is of limited value. The usefulness of B19 IgG assay in patients whose symptoms are long standing is not great, because more than $50 \%$ of adults in the United Kingdom have this antibody whether or not they have a history of arthritis, and the seroprevalence increases to more than $75 \%$ in those older than 50 years. ${ }^{13}$ One early study did find a greater prevalence of B19 IgG in chronic arthritis patients compared with controls, ${ }^{14}$ but this was not confirmed by others, ${ }^{15}$ and needs to be repeated using the newer B19 IgG assays available. A negative $B 19$ IgG result excludes a past infection with $\mathrm{B} 19$ virus, but a positive result may have no pathological significance, merely reflecting past acquisition of antibody, mostly likely as a result of erythema infectiosum or asymptomatic infection in childhood.

Nikkari et $a l^{8}$ detected parvovirus B19 specific gene sequences by polymerase chain reaction (PCR) in two patients with early arthritis fulfilling criteria for rheumatoid arthritis, but the disease was progressive and erosive in only one case. Caution must be exerted in interpreting these results. Positive PCR findings in serum are not limited to the acute phase, but can be made for many months afterwards, even in completely resolving B19 infection in immunocompetent hosts without clinical sequelae. ${ }^{16}$ The presence of B19 DNA at this stage of convalescence may merely reflect the stochastic decay ${ }^{16}$ of a biological entity, $B 19$ virus, which is both stable and initially present at an extremely high concentration in the blood. The persistence of B19 DNA at other sites of the body, especially in synovial material, may have greater significance, but does not prove causation as it may be a mere passenger in one of the cell populations attracted to the inflamed synovium. Preliminary PCR studies targeted on these areas have been performed, ${ }^{17}{ }^{18}$ but have so far been limited by lack of suitable control samples. It would be helpful in future PCR investigations to develop assays that are both quantitative (so that a clinically significant level of B19 DNA can be determined) and discriminatory between replicating forms of B19 DNA or RNA and virion associated DNA. This might allow current B19 infection to be differentiated from a recent acute infection. The question of whether $B 19$ virus is a persistent infection or a trigger in chronic arthritis may then be addressed. Until then, the role of B19 in rheumatoid arthritis remains speculative.

There is, however, a clear role of B19 in acute arthropathy, which may initially present as indistinguishable from rheumatoid arthritis, and it is important to appreciate the limitations of presently available diagnostic procedures. Here the diagnosis rests on demonstrating B19 specific IgM, but as this marker is only present for two to three months after onset of symptoms it is only useful when early presenting cases are being examined. Specific IgM serology is not worthwhile in patients presenting more than three months after disease onset and may be complicated by the presence of rheumatoid factor, which generates nonspecific reactions in some B19 IgM assays. Caution must also be shown with some recent commercial B19 IgM assays which have unproven specificity and sensitivity; results should be confirmed by a reference B19 IgM assay or by some other procedure, for example, IgG avidity assay. ${ }^{19}$ As the majority of cases have a good outcome, ${ }^{9}$ diagnosis of parvovirus B19 arthropathy will allow reassurance of the patient and appropriate conservative treatment.

Department of Rheumatology,

A D WOOLF

Royal Cornwall Hospital,

Truro, Cornwall TR1 $2 \mathrm{HZ}$,

United Kingdom

PHLS Virus Reference Division, Colindale, London NW9 5HT, United Kingdom

1 Anderson M J, Jones S E, Fisher-Hoch S P, et al. Human parvovirus, the cause of erythema infectiosum (fifth disease)? Lancet 1983; i: 1378.

2 Anderson M J, Davis L R, Hodgson J, et al. Occurrence of infection with a parvovirus-like agent in children with sickle cell anaemia during a twoyear period. 7 Clin Pathol 1982; 35: 744-9.

3 Brown T, Anand A, Ritchie L D, Clewley J P, Reid T M S. Intrauterine parvovirus infection associated with hydrops fetalis. Lancet 1984; ii: 1033-4.

4 Finkel T H, Torok T J, Ferguson P J, et al. Chronic parvovirus B19 infection and systemic necrotising vasculitis: opportunistic infection or aetiological agent? Lancet 1994; 343: 1255-60.

5 Nikkari S, Mertsola J, Kovenranta H, Vainionpaa R, Toivanen P. Wegener's granulomatosis and parvovirus B19 infection. Arthritis Rheum 1994; 37: 1707-8.

6 White D G, Woolf A D, Mortimer P P, Cohen B J, Blake D R, Bacon P A. Human parvovirus arthropathy. Lancet 1985; i: 419-21.

7 Reid D M, Reid T M S, Brown T, Rennie J A N, Eastmond C J. Human parvovirus-associated arthritis: a clinical and laboratory description. parvovirus-associated

8 Nikkari S, Roivainen A, Hannonen P, et al. Persistence of parvovirus B19 in synovial fluid and bone marrow. Ann Rheum Dis 1995; 54: 597-600.

9 Woolf A D, Campion G V, Chishick A, et al. Clinical manifestations of human parvovirus B19 in adults. Arch Intern Med 1989; 149: 1153-6.

10 Luzzi G A, Kurtz J B, Chapel H. Human parvovirus arthropathy and heumatoid factor. Lancet 1985 ; i: 419-21.

11 Tyndall A, Jelk W, Hirsch H H. Parvovirus B19 and erosive polyarthritis. Lancet 1994; 343: 480-1. 
12 Evans A S. Causation and disease: the Henle-Koch postulates revisited. Yale f Biol 1976; 49: 175-95.

3 Cohen B J, Buckley M M. The prevalence of antibody to human parvovirus B19 in England and Wales. F Med Microbiol 1988; 25: 151-3.

14 Cohen B J, Buckley M M, Clewley J P, Jones V E, Puttick A H, Jacoby $\mathrm{R} K$. Human parvovirus infection in early rheumatoid and inflammatory arthritis. Ann Rheum Dis 1986; 45: 832-8.

15 Lefrere J J, Meyer O, Menkes C J, Beaulieu M J, Courouce A M. Human parvovirus and rheumatoid arthritis. Lancet 1985; i: 982.

16 Clewley J P. Polymerase chain reaction assay of parvovirus B19 DNA in clinical specimens. f Clin Microbiol 1989; 27: 2647-51.
17 Foto F, Saag K G, Scharosch I J, Howard E J, Naides S J. Parvovirus B19-specific DNA in bone marrow from B19 arthropathy patients: evidence for B19 virus persistence. F Infect Dis 1993; 167: 744-8.

18 Saal J G, Steile M, Einsele H, Muller C A, Fritz P, Zacker J. Persistence of B19 parvovirus in synovial membranes of patients with rheumatoid arthritis. Rheumatol Int 1992; 12: 147-51.

19 Gray J J, Cohen B J, Desselberger U. Detection of human parvovirus B19-specific IgM and IgG antibodies using a recombinant viral VPI Bl antigen expressed in insect cells and estimation of time of infection by

\section{New questions about the muscular dystrophies}

Neurologists, being interested in locating lesions in the nervous system, tend to think of muscles as organs, each with its unique nerve supply, rather than of muscle as a tissue. The rather consistent selective patterns of muscle wasting and hypertrophy which characterise each of the muscular dystrophies disappointingly still defy explanation and have to be learned by rote. Until very recently, diagnosis of the many types of muscular dystrophy has been based wholly on recognising these patterns, together with information on the onset and progression of symptoms, the serum creatine kinase activity and the family history. Even the histology in most types is consistent rather than diagnostic, and is useful mainly to exclude other quite different disorders. Since 1987, when deletions of the Duchenne gene and dystrophin assays were first used in diagnosis, this situation has begun to change and in the last few months of 1994 the point was reached when most of the common types of muscular dystrophy could be diagnosed by tests of genes or their products. The table summarises some of this new information.

Rheumatologists may encounter these disorders mainly when patients present with pain or contractures. Such symptoms tend to be local and may divert attention from widespread muscle wasting and weakness, so slowly progressive that the patient may be quite unaware of them. The most useful diagnostic instruments in this situation are the corridor and the staircase; if walking looks normal, running may bring out an obvious abnormality of gait. If watching the patient in action shows that there is a problem, detailed muscle examination will go a long way towards identifying it.

\section{Pain}

Pain is not a common feature of most muscular dystrophies, apart from the mild aching after exercise that occurs in anyone with muscle weakness, and no muscular dystrophy (MD) causes pain in the absence of physical signs. Calf pain during and after exercise is much more frequent in Becker MD than in other types, and may be comparable in severity to that seen in glycogen storage diseases such as McArdle's disease. It is quite often the presenting feature in subjects between the ages of about 5 and 25 years. The calves in Becker $\mathrm{MD}$ are usually obviously hypertrophic while the quadriceps, brachioradialis, costal origin of pectoralis major, and the latissimus dorsi are selectively atrophied. This distribution is seen also in the more severe Duchenne $\mathrm{MD}$, but calf pain is not so frequent. Female carriers of the $\mathrm{X}$ linked gene for these two disorders sometimes manifest a mild degree of muscular dystrophy, and calf pain and hypertrophy are two quite frequent features in such women. In cases and manifesting carriers of Duchenne and Becker MD, the serum creatine kinase concentration is always considerably increased.

Pain is also common in facioscapulohumeral (FSH) MD, though not usually at the onset. This autosomal dominant disorder (figure) causes weakness of closure of the eyes and lips, winging and elevation of the scapulae on abduction of the arms, and selective wasting of biceps, triceps and tibialis anterior, but spares the muscles of the forearms and generally also the proximal muscles of the lower limbs. It varies greatly within families in onset and severity. Four of its peculiar features, though not by any means present in every case, are asymmetry of involvement; the occasional occurrence of subacute episodes of permanently increased weakness affecting one or more muscles, typically in the upper arm and typically after exercise or occurring on the dominant side; pain in affected muscles, rather constant but worse on movement; and inflammatory in addition to dystrophic changes in the muscle biopsy. These four features are not always seen together and they have so far eluded explanation. Other than in sometimes having infiltration by inflammatory cells, the myopathy of FSH does not resemble polymyositis. A subclinical retinal vasculopathy, akin to Coats' disease, is a feature of FSH MD, ${ }^{5}$ but there is no evidence

Diagnosis of the common types of muscular dystrophy by tests of genes or their products ${ }^{1-4}$

\begin{tabular}{|c|c|c|c|}
\hline Muscular dystrophy & Gene site & Detectable gene lesions & Gene product \\
\hline $\begin{array}{l}\text { Duchenne } \\
\text { Becker } \\
\text { Emery-Dreifuss } \\
\text { Severe autosomal recessive } \\
\text { MD childhood (SCARMD2) }\end{array}$ & $\begin{array}{l}\text { Xp21 } \\
\text { Xp21 } \\
\text { Xq28 } \\
17 q 12-21\end{array}$ & $\begin{array}{l}\text { Deletions in } 60 \% \text {, a few duplications } \\
\text { Deletions in } 80 \% \\
\text { Deletions or insertions } \\
\text { Some point mutations }\end{array}$ & $\begin{array}{l}\text { Dystrophin } \\
\text { Dystrophin } \\
\text { Emerin } \\
\text { Adhalin ( } 50 \mathrm{kDa} \text { DAG) }\end{array}$ \\
\hline $\begin{array}{l}\text { North African (SCARMD1) } \\
\text { Fukuyama } \\
\text { Congenital (some cases) } \\
\text { Facioscapulohumeral† } \\
\text { Myotonic dystrophy }\end{array}$ & $\begin{array}{l}13 \mathrm{q} 12 \\
9 \mathrm{q} 31-33 \\
6 \mathrm{q} 2 \\
4 \mathrm{q} 35 \\
19 \mathrm{q} 13.3\end{array}$ & $\begin{array}{l}\text { Not yet } \\
\text { Not yet } \\
\text { Not yet } \\
\text { Small DNA fragment (probe p13E-11) } \\
\text { Unstable triple repeat (CTG) sequence }\end{array}$ & $\begin{array}{l}\text { Unknown, but secondary } 50 \mathrm{kDa} \text { DAG deficiency } \\
\text { Possibly } 43 \mathrm{kDa} \mathrm{DAG} \\
\text { Merosin (laminin M) } \\
\text { Unknown } \\
\text { Predicted membrane protein kinase }\end{array}$ \\
\hline
\end{tabular}

DAG = Dystrophin associated glycoprotein. (†P E Jardine et al, British Paediatric Neurology Association, Cambridge, 1995.). 